\title{
Investigación en medicina
}

Parafraseando el Credo de la Universidad Favaloro, quiero mencionar que ejercer la Medicina sin investigar en paralelo es inmovilizar su ejercicio en el tiempo, emprender investigaciones médicas sin rigor científico, sólo basándose en el ejercicio de las ciencias básicas, no siempre es investigar, sino emprender aventuras sin fundamento, muchas veces también incompatibles con la ética.

Investigar sin educar, no sólo traiciona la esencia del acto creador, sino que priva a las generaciones venideras de la riqueza invalorable de descubrir su propio potencial creativo. Pero, educar sin comprometer a quienes se educa con la realidad social de su tiempo, tampoco es educar, sino entrenar profesionales diestros, cuyas destrezas de poco han de servirle si a causa de su miopía social no pueden ponerlas al servicio de quienes más las necesitan.

He tenido el gran honor de ser invitado a escribir estas líneas, a modo de introducción de esta primera edición de la Revista Medicina e Investigación Clínica Guayaquil, augurando un futuro prometedor y también comprometiéndome a aportar toda mi experiencia en futuras ediciones.

Eduardo Galeano dijo que las utopías sirven para seguir caminando, y especialmente cuando nos referimos a la medicina, estas utopías tarde o temprano se transforman en realidad como resultado del trabajo perseverante de quienes están dispuestos a seguirlas. El esfuerzo de esta primera edición ha sido de muchos, pero no puedo dejar de mencionar a la Dra. Mónica Gilbert, alumna, discípula y tenaz profesional, que a pesar de su juventud ha sabido vislumbrar la importancia de emprender esta aventura, de poner sobre sus hombros este proyecto y trabajar incansablemente para que se concrete.

Roberto René Favaloro 